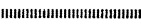 論 文 $\mathrm{SCM} 420 \mathrm{H}$ 鋼の被削性に及ぼす脱硫の影響

(C) 1983 ISIJ

\section{Effect of Desulfurization on the Machinability of SCM420H Steel}

\author{
Hideharu Fununaga and Tadahisa Akasawa
}

\begin{abstract}
Synopsis :
\end{abstract}
Machinability of low alloy steels with extra-low and ordinary sulfur contents was studied by means of turning tests using sintered carbide tools under conventional machining conditions. The results are as follows. Reduction in sulfur contents decreases chip breakability, improves surface roughness and topography at cutting speeds of $100 \mathrm{~m} / \mathrm{min}$ or higher, and exerts only a minor effect on tool life and cutting forces. On the whole, the desulfurized steel can be machined at a high removal rate without any serious problem, provided proper cutting conditions are selected and the smooth machined surface thus obtained promises a good tribological effect.

It was discussed and found that there was no difference between the mechanisms accounting for the effects of desulfurization and those of resulfurization on the machinability of steel.

\section{1. 緒}

\section{言}

近年，鋼の脱硫技術の向上にともなつて，極めて S 含 有量の低い鋼を溶製することが可能になつてきた ${ }^{1)}$ 。鋼 中の $\mathrm{S}$ 含有量を低減すると，冷間加工性や耐転がり疲れ 強さが改善される．ところが S はよく知られた快削添加 元素であるから， S を低減することによつて被削性が極 端に悪化しないかと䀣念される.JIS によれば低合金肌 焼鋼の $\mathrm{S}$ 量は $0.03 \%$ 以下と規定されており，従来の市 販品は $0.02 \%$ 程度の $\mathrm{S}$ 含有しているものが多い2). また，我が国で自動車用などに 0.04〜0.07\% した $\mathrm{S}$ 快削肌焼鋼や強勒鋼も使用されており ${ }^{3)}$ ，米国で は 0.035 0.05\% S を添加した SAE 4028 鋼が被削性 のすぐれた歯車材として多用されたことがある4).さら に, 山本ら ${ }^{3)}$ は $0.2 \%$ 程度までSを添加した SGM 21 の被削性を調べている. したがつて，約 $0.02 \%$ 以上の $\mathrm{S}$ 含有量の被削性に及ぼす影響を経験的にも知ることが できるが，それ以下に脱硫したときの低 $\mathrm{S}$ 含有量の影響 は新しい問題であり，その調査報告がみあたらない。こ の研究は S を低減した肌焼鋼の被削性を調べ，その結果 が S を添加した場合の被削性に関する従来の知見を外挿 して得られるかどらかを検討したものである.

\section{2. 被削材および実験方法}

\section{$2 \cdot 1$ 被削材}

実験に用いた被削材は低合金肌焼鋼 (SCM $420 \mathrm{H})$
である. 被削材の記号とチェック分析結果を Table 1 に示す. YA 材は脱硫処理を施して S 量を $0.002 \%$ ま で低減したものであり，YS 材は JIS のほ汇上限の S 量 $0.031 \%$ を含有しており，以後それぞれ脱硫鋼および通 常鋼と呼ぶ. NH および NS 材は精機学会切削性専門 委員会での共同研究に使用された鋼で, 広く被削性が調 查されている5)ので，本実験との比較の意味で使用した. また，NHと NS 材は焼ならし温度が後述 Table 2 に 示すよらに異なるが，その被削性は大同小異であること があらかじめわかつている5). なお, Table 1 より, 不 純物元素および合金添加元素量は 3 種の被削材ともあま り違つていないといえる. YA および YS 材は $500 \mathrm{~kg}$ の高周波誘導溶解炉で溶解し, 所定の精錬を経て直 径 $100 \mathrm{~mm}$ の丸棒に鍛造した. NH および NS 材は $50 \mathrm{t}$ 電気炉を用いた量産設備による通常溶解法によるもの で, 直径 $75 \mathrm{~mm}$ の圧延棒材である. YA および YS 材 に Table 2 に示す焼ならし処理を施し被削材とした. な拉，Table 2 には NH, NS 材の処理条件および各材 の熱処理後の硬さも併記した. Table 3 は被削材の常温 および高温 $\left(700^{\circ} \mathbf{C}\right)$ に打ける機械的性質を示したもの である.これらの表から，被削材の機械的性質は全般的 に大きな差はないが，常温において脱硫鋼の伸びおよび 絞りが若干すぐれており，NH および NS 材は硬さお よび降伏点が若干高い.

3 つの被削材の顕微鏡組織はいずれも通常の焼ならし 組織を呈し，その差はほとんど認められなかつた.

昭和 55 年 10 月本会講演大会にて発表 昭和 57 年 11 月 26 日受付 (Received Nov. 26, 1982)

* 広島大学工学部 工博 (Faculty of Engineering, Hiroshima University, Shitami Saijo-cho Higashihiroshima 724)

*2 新日本製鉄 (株)製品技術究研所 (Products R \& D Laboratories, Nippon Steel Corp.) 
Table 1. Ghemical compositions of work materials (SCM $420 \mathrm{H}$ ). (wt \%)

\begin{tabular}{|c|c|c|c|c|c|c|c|c|c|c|c|c|c|c|}
\hline Steels & G & $\mathrm{Si}$ & $\mathrm{Mn}$ & $\mathrm{P}$ & $\mathrm{S}$ & $\mathrm{Cr}$ & Mo & $\begin{array}{l}\text { sol } \\
\mathrm{Al}\end{array}$ & $\begin{array}{c}\text { insol } \\
\mathrm{Al}\end{array}$ & $\begin{array}{l}\text { sol } \\
\mathrm{N}\end{array}$ & $\underset{N}{\text { insol }}$ & $\mathrm{O}$ & $\mathrm{SiO}_{2}$ & $\mathrm{Al}_{2} \mathrm{O}_{3}$ \\
\hline YA & 0.20 & 0.27 & 0.77 & 0.015 & 0.002 & 1.04 & 0.25 & 0.030 & 0.004 & 0.0092 & $<0.001$ & 0.0042 & 0.0006 & 0.0077 \\
\hline YS & 0.20 & 0.22 & 0.81 & 0.016 & 0.031 & 1.06 & 0.23 & 0.014 & 0.005 & 0.0047 & $<0.001$ & 0.0061 & 0.0006 & 0.0091 \\
\hline $\begin{array}{l}\mathrm{NH} \\
\mathrm{NS}\end{array}$ & 0.19 & 0.29 & 0.76 & 0.019 & 0.005 & 1.03 & 0.18 & \multicolumn{2}{|c|}{$\begin{array}{l}\text { Total } \\
0.045\end{array}$} & \multicolumn{2}{|c|}{$\begin{array}{l}\text { Total } \\
0.0105\end{array}$} & 0.0031 & - & - \\
\hline
\end{tabular}

Table 2. Heat-treatment and hardness of work materials.

\begin{tabular}{ccc}
\hline Steels & Heat-treatment $\left({ }^{\circ} \mathrm{C} \times \mathrm{h}\right)$ & Hardness (HRB) \\
\hline YA & $900 \times 4$, Air cooling & 78.6 \\
YS & $900 \times 4$, Air cooling & 78.7 \\
NH & $1000 \times 2$, Air cooling & 85.5 \\
NS & $870 \times 2$, Air cooling & 82.0 \\
\hline
\end{tabular}

Table 3. Mechanical Properties of work materials.

(a) At room temperature

\begin{tabular}{|c|c|c|c|c|}
\hline Steels & $\begin{array}{l}\text { Yield strength } \\
\left(\mathrm{kgf} / \mathrm{mm}^{2}\right)\end{array}$ & $\begin{array}{l}\text { Tensile strength } \\
\left(\mathrm{kgf} / \mathrm{mm}^{2}\right)\end{array}$ & $\begin{array}{l}\text { Elongation } \\
(\%)\end{array}$ & $\begin{array}{l}\text { Reduction } \\
\text { of area } \\
(\%)\end{array}$ \\
\hline YA & 29.9 & 53.4 & 39.1 & 69.6 \\
\hline YS & 29.2 & 51.5 & 35.5 & 68.2 \\
\hline $\mathrm{NH}$ & 34.7 & 61.1 & 30.9 & 64.0 \\
\hline NS & 34.6 & 58.3 & 33.2 & 67.9 \\
\hline \multicolumn{5}{|c|}{ (b) At $700^{\circ} \mathrm{C}$} \\
\hline Steels & $\begin{array}{l}0.2 \% \text { Proof } \\
\text { strength } \\
\left(\mathrm{kgf} / \mathrm{mm}^{2}\right)\end{array}$ & $\begin{array}{l}\text { Tensile strength } \\
\left(\mathrm{kgf} / \mathrm{mm}^{2}\right)\end{array}$ & $\begin{array}{c}\text { Elongation } \\
(\%)\end{array}$ & $\begin{array}{l}\text { Reduction } \\
\text { of ares } \\
(\%)\end{array}$ \\
\hline YA & 7.2 & 12.7 & 55.5 & 95.1 \\
\hline YS & 7.5 & 13.3 & 62.4 & 88.9 \\
\hline
\end{tabular}

Table 4. Area fractions of inclusions determined by JIS Point-counting method.

\begin{tabular}{ccccc}
\hline Steels & $\mathrm{dA}$ & $\mathrm{dB}$ & $\mathrm{dC}$ & $\mathrm{dT}$ \\
\hline YA & 0.013 & 0.008 & 0.017 & 0.038 \\
YS & 0.108 & 0.021 & 0.017 & 0.146 \\
\hline
\end{tabular}

Table 5. Turning conditions.

\begin{tabular}{lc} 
Cutting speed, $V(\mathrm{~m} / \mathrm{min})$ & $2 \sim 400$ \\
Feed, $f(\mathrm{~mm} / \mathrm{rev})$ & $0.06 \sim 0.3$ \\
Depth of cut, $t(\mathrm{~mm})$ & $0.2,1.0,2.0,3.0$ \\
Tool & P10 $(-5,-5,5,5,15,15,0.4)$ \\
& Chip breaker width, 2.3mm \\
Cutting fluid & None \\
\hline
\end{tabular}

Table 4 は脱硫鋼と通常鋼の清浄度を測定した結果を示

す. $\mathrm{S}$ 含有量を低減すると介在物の全量が少なく, 当然 のことながら，とくにA系介在物の面積率が小さいこと が特徽的である.

\section{$2 \cdot 2$ 切削実験方法}

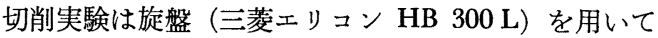
丸棒の外周長手切削を行い，仕上げ面あらさ，工具 摩 耗，切削抵抗および切りくず破砕性を調査した．仕上げ 面あらさとしては万能表面形状測定器（小坂研究所製
SE-3 型) を用いて旋削面の最大高さ $R_{\max }$ を測定し た. 工具摩耗は工具顕微鏡（ライゼン）を用いて平均フ ランク摩耗幅を, また, 万能表面形状測定器（前出）を 用いて最大クレータ深さを求め, それぞれフランク摩耗 $\mathrm{VB}$, クレータ摩耗 $\mathrm{KT}$ とした. 切削抵抗は工具動力計

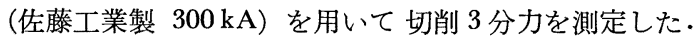
使用した工具は超硬 P 10 のスローアウェイ型であり, その他の切削条件をまとめて Table 5 に示す. な括, 比較のため上記以外の切削条件も採用したが，それらに ついてはとの都度記すこととし, 切削速度, 送りおよび 切り込み量の記号として，それぞれ， $V, f$ および $t$ を 用いる。

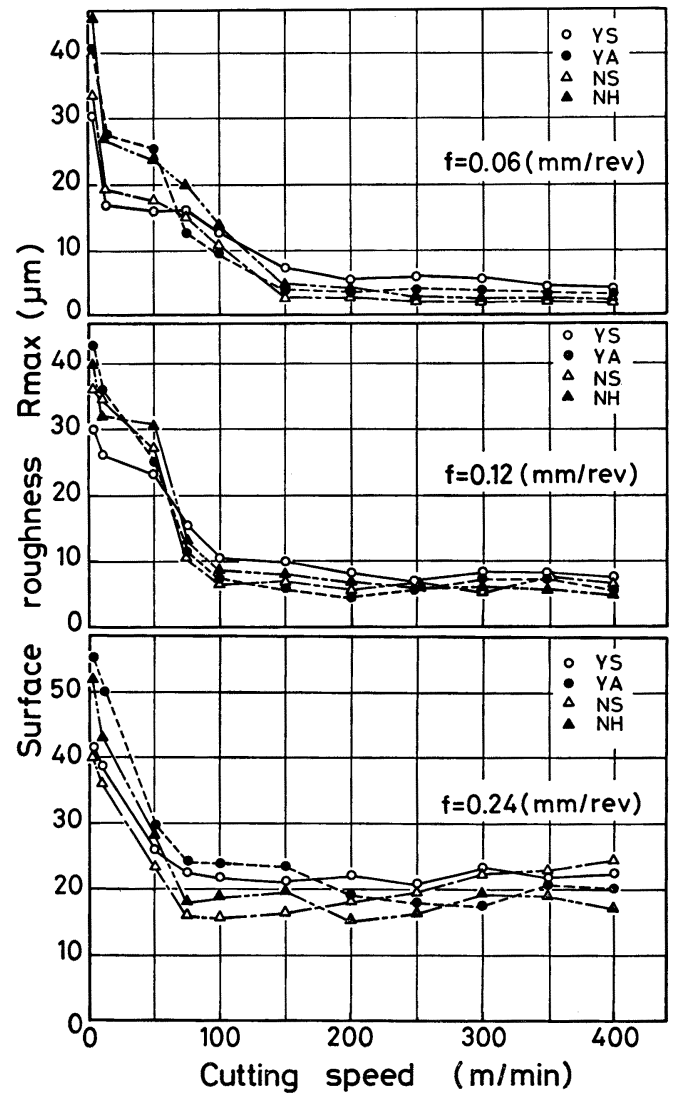

Fig. 1. Surface roughness of work materials $(t=0.2 \mathrm{~mm})$. 

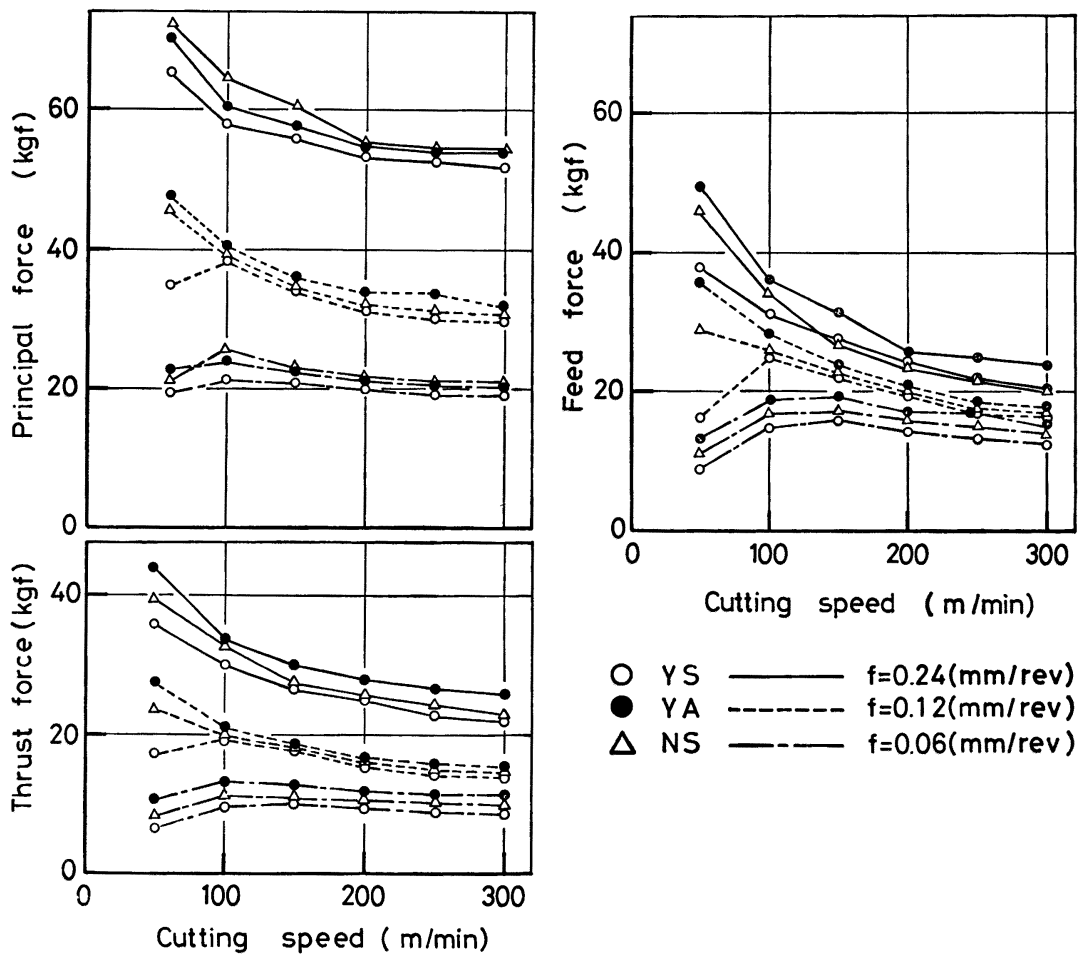

Fig. 2. An example of cutting forces of work materials $(t=1.0 \mathrm{~mm})$.

\section{3. 実 験 結 果}

\section{1 切削仕上げ面あらさ}

Fig. 1 は切り込み $0.2 \mathrm{~mm}$ で送りと切削速度を変え て各種の被削材を旋削したときの仕上げ面あらさの平均 值を示す，通常鋼の YS 材と脱硫鋼の YA 材を比較す ると，いずれの送りの場合でも，仕上げ面あらさは低切 削速度域では $\mathrm{S}$ 含有量の高いYS 材の方が小さく, 中 間の切削速度域で逆転し, 高切削速度域になると $\mathrm{S}$ 含有 量の低いYA 材の方が小さくなることがわかる．また， いずれの被削材に抢いても，仕上げ面あらさが切削速度 に対してほぼ一定になるいわゆる臨界切削速度6) が存在 し，その值は送りの大きさに依存することが明らかに認 められるが，被削材の種類によつてはほとんぞ変わらな いとい光る. 臨界切削速度は送り $0.06,0.12$ および $0.24 \mathrm{~mm} / \mathrm{rev}$ のとき，それぞれ，約 150,100 および 75 m/min であり, その速度に達するとすでに 脱硫鋼の方 が通常鋼より仕上げ面あらさが小さくなる逆転現象は完 了しているとみなすことができる.

\section{2 切削抵抗}

切り込みを $1.0 \mathrm{~mm}$ と一定にして，切削速度と送り を変えて切削主分力, 送り分力および背分力を調べた.
Fig. 2 はそれらの結果の一例を示す。すべての 被削材 について, 切削抵抗の切削速度および送り依存性は通常 の鋼を切削したときに見られる結果と何ら変わらない。 そのなかで, YS 材と YA 材の差について着目すると, 常に YS 材の切削主分力が YA 材のとれより 5\% 程 度小さい值となつている．この傾向は切削送り分力およ び背分力に関しても変わらない，また，切り込みを 0.2 $\mathrm{mm}$ に減じて上と同様の実験を行つたが，切削抵抗の測 定結果は同じ傾向であつた。すなわち， S 著しく減じ ても，切削抵抗は大幅には增加しない。

脱硫鋼の切削抵抗が通常鋼よりも大きいのは， $\mathrm{S}$ を減 じたことによる脱硫鋼の属性，すなわち，硫化物系介在 物の減少にとるない, 延性が改善されたことに起因する と考光られるが硫化物系介在物の大幅な減少割合に対 し, 切削抵抗の増加は僅少である.

\section{$3 \cdot 3$ 工具摩耗}

一定の切削条件で各被削材を旋削したときのフランク 摩耗進行曲線の一例を Fig. 3 亿示す.この図にみられ るように，工具摩耗は YS 材を削つたときよりも Y A 材を削つたときの方が少し大きくなつている．切削速度 を変えて，フランク摩耗拉よびクレータ摩耗の進行を調 ベたところ，常に YS 材より YA 材において工具摩耗 


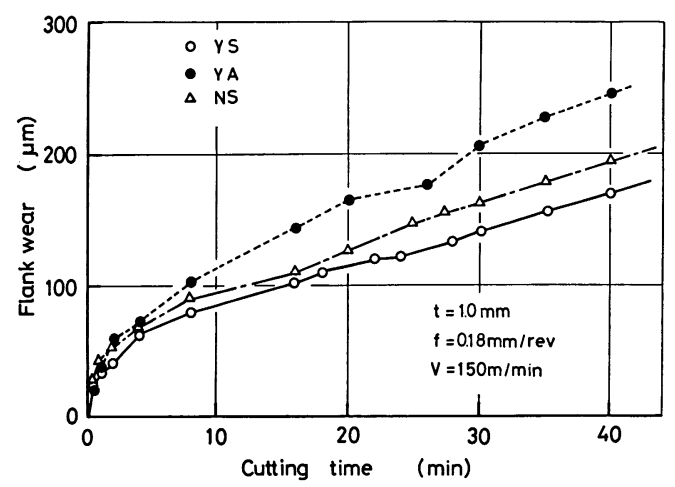

Fig. 3. An example of the flank wear curves $(t=1.0 \mathrm{~mm}, V=150 \mathrm{~m} / \mathrm{min}, f=0.18 \mathrm{~mm} / \mathrm{rev})$.
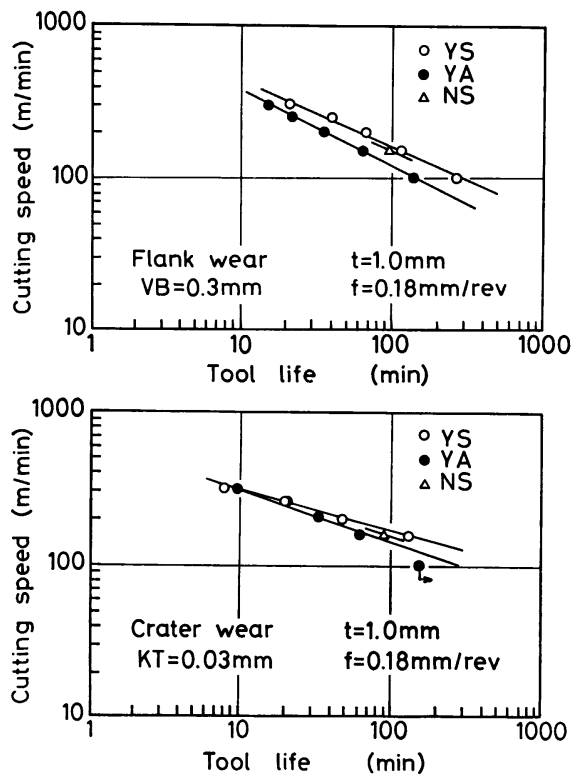

Fig. 4. The V-T curves of desulfurized and ordinary SCM $420 \mathrm{H}$ steel, determined by the wear criterion on the flank and crater for 0.3 and 0.03 $\mathrm{mm}$, respectively.

が若干大きいことが認められた.これらの結果をまとめ て V-T 線図で示すと Fig. 4 のよらになる.

\section{4 切りくずの破砕性}

切りくずの切れやすさを評価するために，いろいろな 切り込みと送り条件で各被削材を旋削し, 得られた切り くずの形態を分類して Fig. 5 に示す. 切りくずの形態 分類は中山ら9)の手法にもとついた. Fig. 5 において斜 線を施した線より上の領域では切りくずが連続しないで 切断し，下の領域では切りくずが連続して発生すること を示す．一般にこの限界線が左下方にあればあるほど， 小さい切り込み，小さい送りでも切りくずが切れること を示すので切りくず破砕性が良いとみなせる，3 種の被
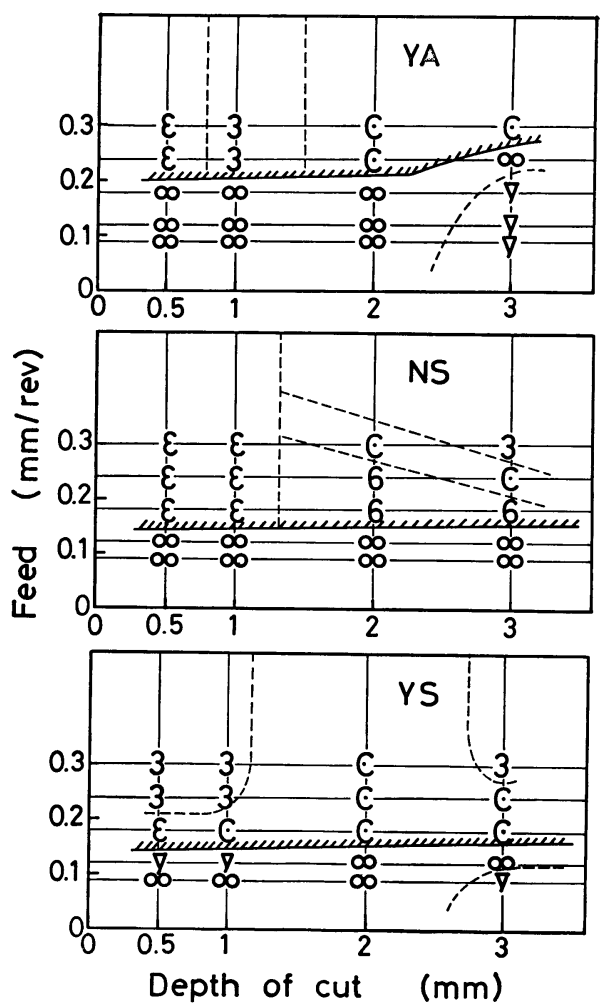

Fig. 5. Morphrogy of machined chip of work materials $(V=150 \mathrm{~m} / \mathrm{min})$.

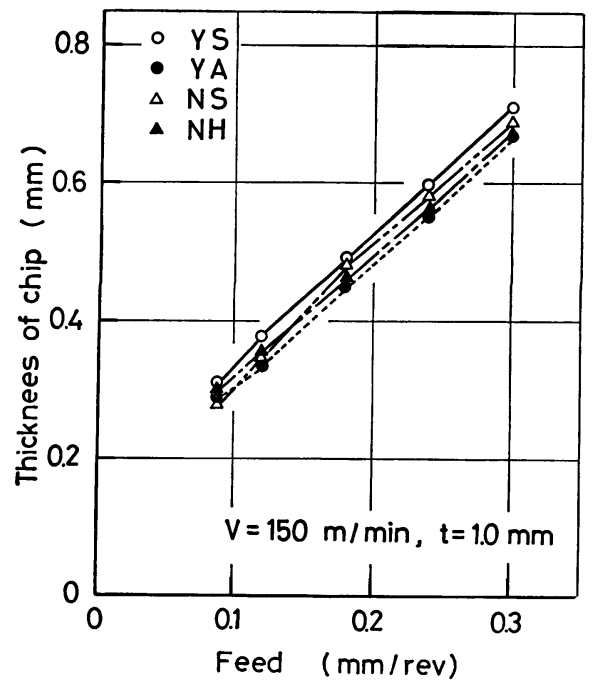

Fig. 6. Chip thickness of work materials $(t=1.0$ $\mathrm{mm}, V=150 \mathrm{~m} / \mathrm{min}, f=0.18 \mathrm{~mm} / \mathrm{rev})$.

削材を比較すると，切りくず破砕性が最も悪いのは YA 材であり，つぎに NS 材が悪く，YS 材が最も良い，千 ップブレーカーをつけているのでその差はあまり大きく 


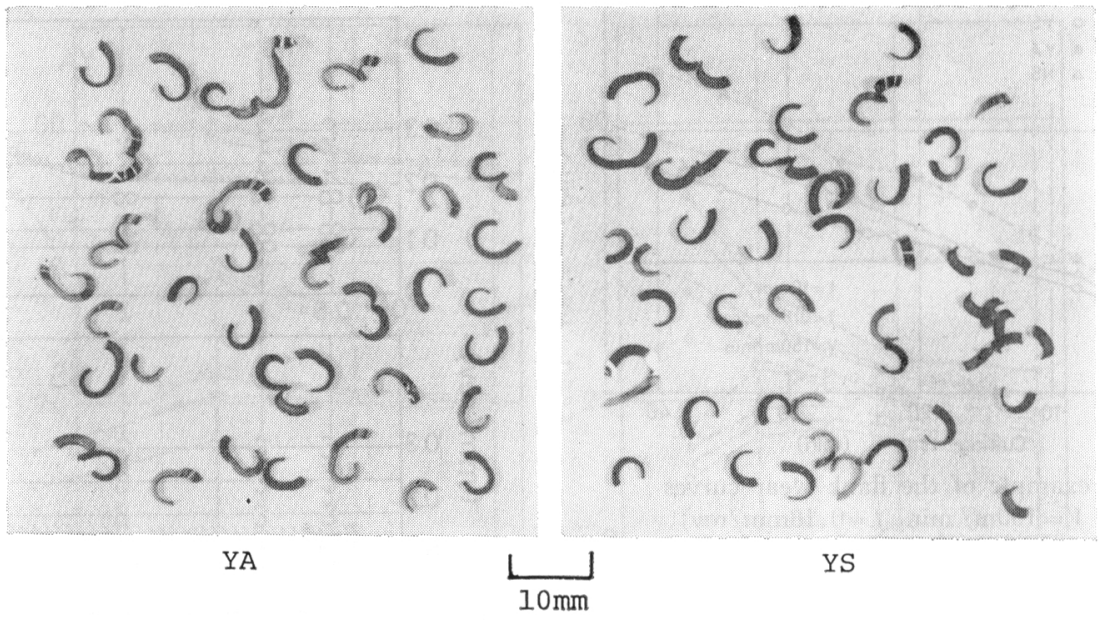

Photo. 1. Photographs of chips, showing similar chip formation between desulfurized and ordinary SCM $420 \mathrm{H}$ steels under the given cutting condition as shown in Table 6.

Table 6. Tool wears of desulfurized and ordinary SCM $420 \mathrm{H}$ steel under the condition of a suitable chip-breaking. $(\mu)$

\begin{tabular}{|c|c|c|c|c|c|}
\hline \multirow{2}{*}{ Steels } & \multicolumn{2}{|c|}{ Side relief face } & \multicolumn{2}{|c|}{ End relief face } & \multirow{2}{*}{$\frac{\text { Rake face }}{\text { KT }}$} \\
\hline & VB & $\mathrm{VN}$ & VB & $\mathrm{VN}$ & \\
\hline YA & 236 & 336 & 116 & 246 & 21.0 \\
\hline YS & 207 & 341 & 170 & 240 & 22.5 \\
\hline
\end{tabular}

Cutting conditions: P20 $(-6,-6,6,6,15,15,0.8), \quad V=250$ $\mathrm{m} / \mathrm{min}, f=0.18 \mathrm{~mm} / \mathrm{rev}, t=1.0 \mathrm{~mm}$, Cutting time $8 \mathrm{~min}$, chip breaker width $1.5 \mathrm{~mm}$, dry.

あらわ机ていないが，それでも切り込みが $3 \mathrm{~mm}$ 程度 に大きいときは YA 材に沶いて切りくずがかなり切れ にくいことがわかる.

YA 材の切りくずが切れにくい原因の一つは, Fig. 6 に示すよらに YA 材の方が Y S 材上り薄い切りくずを 発生させるからである。すでに述べたように被削性に及 ぼす脱硫の影響は小さく，実用切削上あまり問題はない 程度と判断される. しかし, 同一の切削条件で通常鋼で は切りくずが切断するが脱硫鋼では連続して発生するよ うな場合は実際上問題となる。 そこで, 一定の切削条件 の下で, チップブレーカ幅のみを調整してほぼ同じ形態 の切りくずが発生する (Photo. 1) ようにして, 工具の 摩耗を調べた。 Table 6 はとのような条件での超硬工具 P $20(-6,-6,6,6,15,15,0.8)$ の摩耗を示す. この 結果によれば, 横切刃のフランク摩耗はやはり YS 材 より YA 材を削つた場合の方が大きいが，クレータ摩 耗や境界摩耗は両者の間にあまり差がない。したがり て，切りくず形態を制御して適当に折れるよらにした実 用の切削加工条件でも脱硫鋼の切削は十分行えるといえ 上ら.

\section{5 考 察}

$3 \cdot 5 \cdot 1$ 仕上げ面あらさ

通常の鋼にSを $0.1 \sim 0.3 \%$ 添加すると, $\mathrm{MnS}$ の増 加によつて, 低切削速度域では刃先より前方での 被削 材の破壊が軽減されるために仕上げ面めらさが改善さ れ ${ }^{10) 11)}$, 高切削速度域では構成刃先の消隇与る限界切削 速度 ${ }^{12)}$ が高くなるために仕上げ面が悪くなる10)ことが知 られている。また, 臨界切削速度は, 構成刃先の核があ つても成長しないよらな切削速度で, 見かけ上は限界切 削速度と一致する10)12)13)。本実験では, 通常の鋼から脱 硫して $\mathrm{S}$ 量を 1 桁程度減じたとき，仕上げ面あらさに及 ぼすSの効果を調べたところ，実験の範囲内で 2 つの鋼 の間に臨界切削速度の差を見出すことはできなかつた が，仕上げ面あらさに及活す $\mathrm{S}$ の効果は従来のものと同 じ傾向であつた。すなわち, 脱硫鋼に対し, 通常鋼を $\mathrm{S}$ 添加鋼とみなすことによつて, 従来の結果および改善機 構を適用することができる。

Photo. 2 は昌運カズヌーブ旋盤を用いて超硬工具 P $20(-6,-6,6,6,15,15,0.8)$ で, YA および YS 材を旋削した仕上げ面のSEM 写真で，仕上げ面の幾何 学的品位を比較したものの代表的な例を示す。气れによ ると，低速での仕上げ面はいずれの鋼材とも材料が破壊 した面で構成された粗い面となつている。一方高速での 仕上げ面は YA 材に扎いて工具の通過面が非常に滑ら かな面であるのに対し，YS 材に特いては微小なむしれ や凹みが多数混在する面となつている，後者は，通常鋼 の $\mathrm{S}$ の含有量がわずか $0.031 \%$ であつても，脱硫鋼の $0.002 \% \mathrm{~S}$ に比べると, $\mathrm{S}$ 含有の効果があらわれて脱硫 


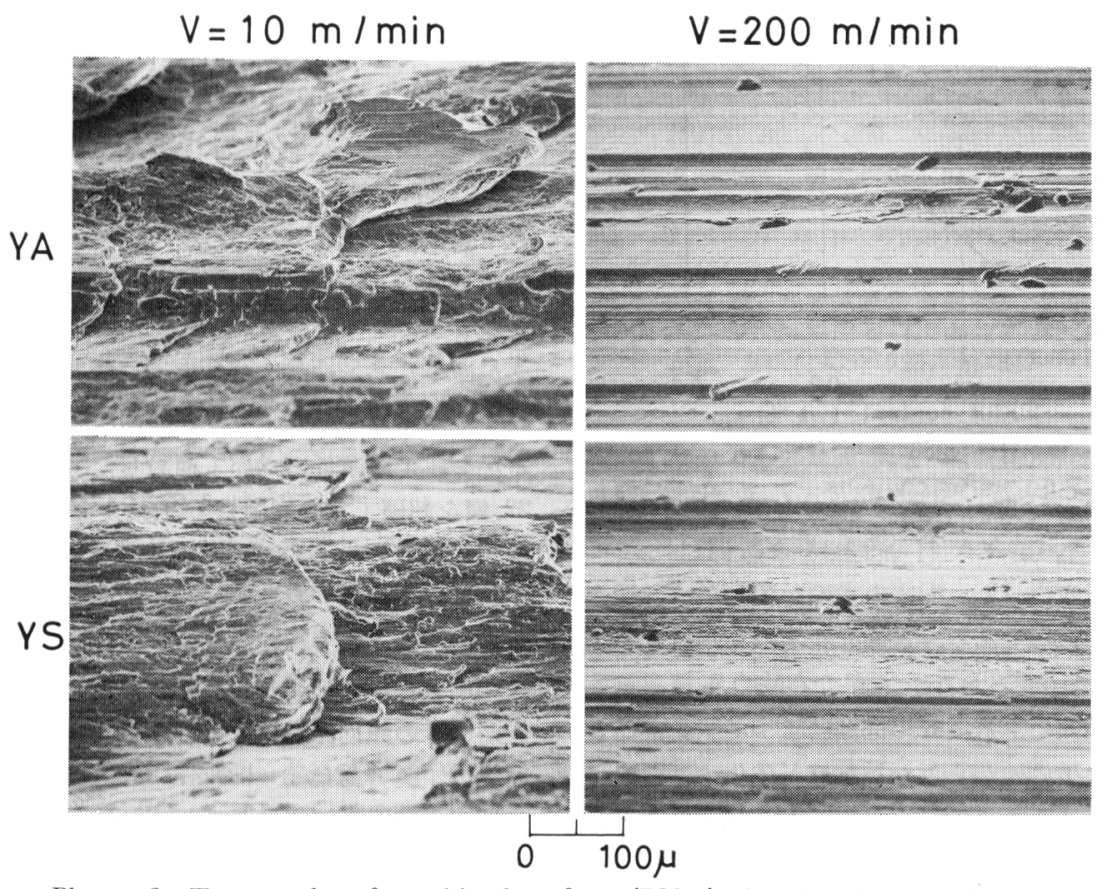

Photo. 2. Topography of machined surface (P20 (-6, -6, 6, 6, 15, 15, 0.8), $t=2.0 \mathrm{~mm}, f=0.12 \mathrm{~mm} / \mathrm{rev})$.

鋼より工具逃げ面に微小な構成刃先様のもの（マイクロ チップ 14)15) が高速域まで発生しやすいためと考觉られ た.このマイクロチップは，逃げ面下に流れこむ金属が 工具逃げ面の微小凸部によつてせきとめられ，その上に 堆積することによつて生成される16)17)。これはみぞ状の 凹みや微小なをしれの発生をよく説明する機構である. 仕上げ面に微小な凹みが発生する過程としては，N．P. SUH ${ }^{18)}$ が唱光た金属摩耗に拈けるデラミネーション説 があげられる。これによれば，仕上げ面が工具逃げ面で 押しつけられながらすべり摩擦をらけるとさ, 表面下で クラックが発生し成長して薄片状の摩耗粉が形成され, そのあとに凹みができると考党られる。マイクロチップ による説も，デラミネーションによる説も微小な破壊の 起点となるものが何かが問題である. D. GILlibRAND ${ }^{19)}$ は第 2 相を含まない純鉄と第 2 相としてパーライトを含 む $0.35 \%$ 炭素鋼を P 20 工具で旋削し，仕上げ面を走 査電子顕微鏡で調べて, 表面の微小なむしれ, 叫及, 穴 やマイクロクラックは第 2 相の存在によつてひき抗こさ れると結論した．脱硫鋼と通常鋼の仕上げ面の差をみる と, パーライトが存在すること以外に非金属介在物の存 在がこれらの什上げ面トポグラフィに影響することが考 壳られ，通常鋼の仕上げ面に見られる微小な欠陷は硫化 物のためであると考えられる.

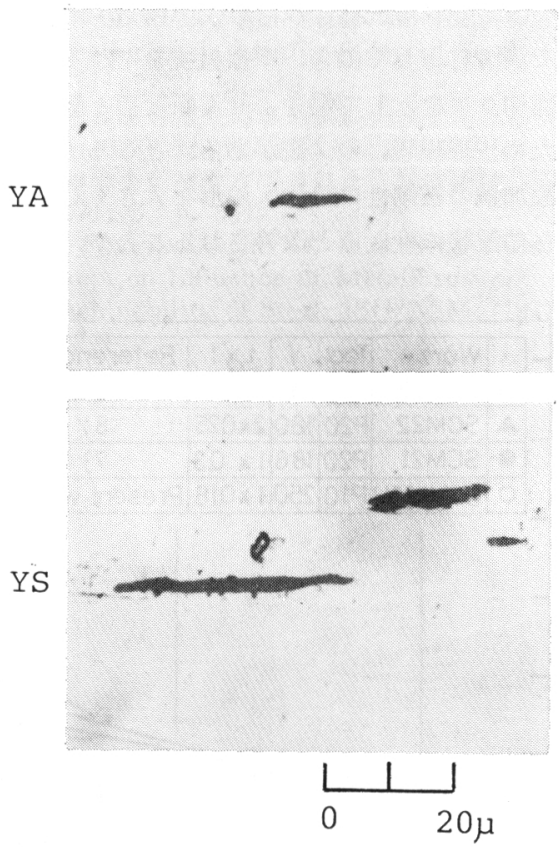

Photo. 3. Morphology of type A inclusions.

$3 \cdot 5 \cdot 2 \mathrm{~A}$ 系介在物の影響

Photo. 3 に YA 材と YS 材のA系介在物の代表的 


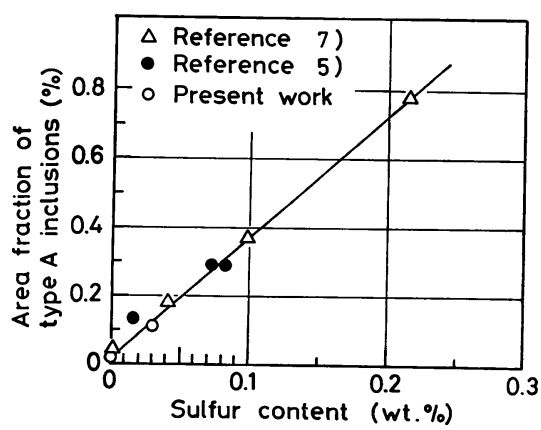

Fig. 7. Relation between area fraction of type A inclusions and sulfur contents.

な顕微鏡写真を示す. YA 材のそれはYS 材に比べて 長さが半分ほどの約 $25 \mu$ 程度のものが多いが，形態そ のものはほぼ相似形である． A 系介在物の存在量を調べ ると, Fig. 7 亿示すと拈り， A 系介在物の面積率と $\mathrm{S}$ 量はほぼ直線関係にある．Ｓの低減によつて工具寿命抒 よび切りくずの破砕性からみた被削性が劣化するのは， A系介在物が小さくなることとその量が低減することの 2つに原因があると思われる。

$\mathrm{S}$ は通常, 鋼中で $\mathrm{MnS}$ となつて存在し, 鍛伸や圧延 によつてA系介在物になる．S 添加することによつて 被削性が改善される機構には，1） $\mathrm{MnS}$ が第 2 次 せん 断領域で潤滑材として働き，摩擦抵抗を下げるため20),

2）内部切り欠きとして働き，せん断変形と破壊を容易 にするため11)15)2122)，の 2 説がある.ところが一般的 に， S 添加鋼の被削性は $\mathrm{MnS}$ の形を大きくしたり，ひ も状から紡鍾状に変光ると改善されることや，超硬工具
のクレータ摩耗痕上に $\mathrm{MnS}$ があまり観察されないこ と 24) 26) によつて，1) よりも2)の機構が主に衝いてい ると考えられる．本実験では $\mathrm{S}$ 量を低隇したとき被削性 の変化を調べたところ，すでに考察した仕上げ面あらさ を除いて，被削性が劣化したが，その機構は上に述べた 2)の説と何ら変わるところがないとい党る。すなおち， 脱硫されて，MnS が小型になる 結果内部切り欠き作用 が弱まり，その絶対量が少なくなる結果応力集中のサイ トが減少して, 被削性が劣化する効果を生じたと考えら れる. その程度が従来の $\mathrm{S}$ 添加鋼に比べぞのくらいであ るかを, 工具摩耗について検討した。 Fig. 8 は SCM 22 鋼を超硬工具で旋削して工具寿命に及ぼす $\mathrm{S}$ 添加の

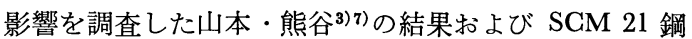
の被削性を調查した精機学会切削性専門委員会の共同研 究8)の結果と本実験の結果を比較したものである.ここ で切削条件が若干異なるので直接比較することはできな いが，その傾向を把握することができる.すなおち，本 研究の工具寿命 $(\mathrm{VB}=0.3 \mathrm{~mm}$ 基準) に及ぼす $\mathrm{S}$ 低減の効 果は従来得られている $\mathrm{S}$ 添加の効果を外插して予測され る程度よりる小さいといえる，S 含有量の低減はこのよ らに工具寿命を減じるが，その程度はあまり大きくない ので，重大な問題を生じることなく切削加工が行えると 考兄れる．末た，この鋼種の被削性全般について，熱 処理の影響2)5) や冷間加工の影響23) を調べた結果と本実 験の脱硫の影響を調べた結果を比較すると, 被削性が悪 化または改善される程度は脱硫の影響の方が小さいか同 程度であり，この面からも実用の生産的加工が克服でき ると結論づけられる，な拉，脱硫鋼は切削仕上げ面の卜

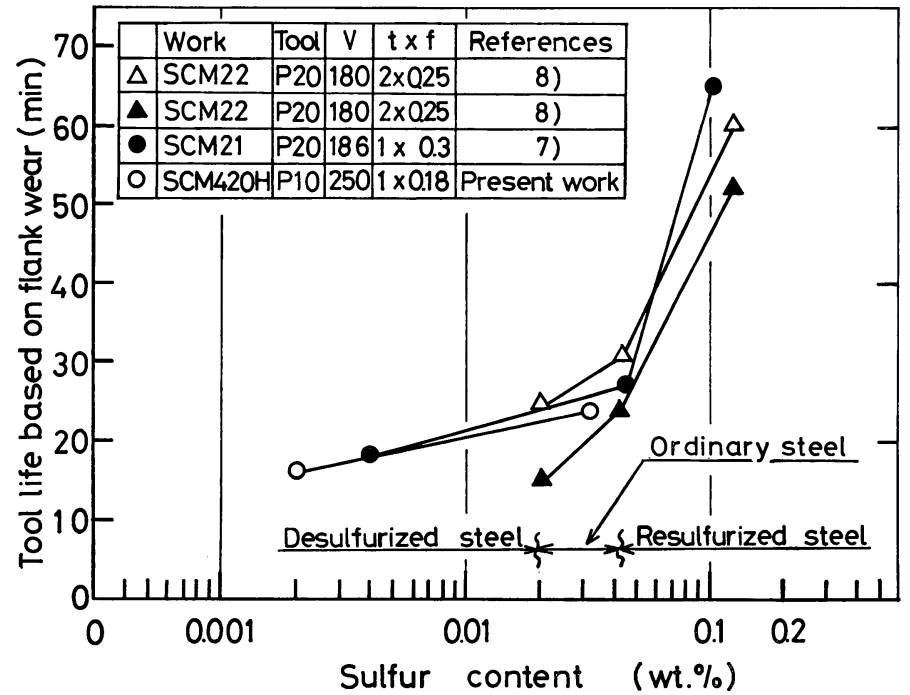

$-120-$
Fig. 8. Effect of sulfur contents on the flank wear. 
ライボロジーからみた改善が大きいので，今後この見地 からこの鋼種の積極的な利用が望まれる.

\section{4. 結言}

被削性に及ぼす極低 S の影響を調べるため，SCM 420 $\mathrm{H}$ の脱硫鋼 $(0.002 \% \mathrm{~S})$ と通常鋼 $(0.031 \% \mathrm{~S})$ の超硬工 具による旋削実験を行つた結果, $\mathrm{S}$ 含有量を低減すると 被削性は次のように変わることが判明した.

1) 臨界切削速度以上の切削仕上げ面のトポグラフィ が異なり，仕上げ面あらさは小さくなる。

2）切削抵抗はいく分大きくなり，工具寿命は短くな るがその程度は小さい。

3）切りくずは薄くなり, 破砕性が悪化する.

これらの結果を総合的にみると，脱硫鋼は切削条件を 適当に選択することによつて，実際上重大な問題を生じ ることなく生産的加工ができると判断され，その際，切 削仕上げ面の品位が改善され，トライボロジカルな効果 が期待できる.な拉，鋼の被削性に及ぼす脱硫の効果之 硫黄添加の効果を考察して, それらの機構の間には何ら 差がないことを示した.

\section{交献}

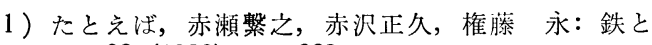
鋼, 66 (1980), p. 662

2 ) $T$. Araki, $H$. Fukunaga, $T$. Sata, and $N$. NARUTAKI: Influence of Metallurgy on Machinability of Steels, ASM, No. 7 (1975), p. 381

3 ) 山本俊郎, 熊谷憲一: 応用機械工学 (1974-4), p. 80

4 ）石原康正：日本金属学会会報，6（1967）3， p. 188

5 ) 精機学会切削加工専門委員会: 精機学会切削加工 専門委員会被削性小委員会研究報告, 第 2 編（昭 和 54 年 4 月)，p. 27
6 ）たとえば，竹山秀彦，大野幸彦，宮坂金佳：精密 機械, 33 (1967) 10，p. 652

7 ) 熊谷憲一：東京大学学位論文，(1976)，p. 133

8 ) 精機学会切削性専門委員会: 精密機械, 39 (1973) 8, p. 809

9 ) 中山一雄: 精密機械, 42 (1976) 2, p. 74

10) M.C. SHAw and J.A. Colwell: 機械と工具, 9 (1965) 3, p. 47, (1964 CIRP 報告訳, 任上 切削)

11）臼井英治：機械試験所報告，(1961-8) 43，p. 1

12）奥島啓式，岩田一明，中谷征司：日本機械学会論 交集，31 (1965) 225，p. 847

13）竹山秀彦，大野幸彦：精密機械，34（1968）8, p. 537

14) 中山一雄: 精密機械, 40 (1974) 3, p. 269

15) $A . W . J$. Chisholm, $W . J$. Wilber, and $E . J$. Pattinson: Ann. GIRP, 21 (1972) 1, p. 7

16) $K$. Nakayama, M.C. Shaw, and $R$. $C$. BreWer: Ann. GIRP, 14 (1966), p. 211

17) P. LANDHERER and J.H. ZAAT: Wear, 27 (1974), p. 129

18) N.P. Sum: Wear, 25 (1973), p. 111

19) D. Gillibrand: Precision Eng., 1 (1979) 2, p. 89

20) M.E. Merchant and N. Zlitin: Trans. ASM, 41 (1949), p. 647

21) J. Hazra, D. Caffarrelli, and $S$. RamalINGAM; Trans. ASME, B97 (1974), p. 1230

22）荒木 透, 山本重男: 精密機械, 42 (1976) 2, p. 68

23) $T$. Itoh, $S$. Abeyama, $A$. Kimura, and $S$. Nakamura: Int. Symp. on Influence of Metallurgy on Machinabilty of Steel, ISIJ/ ASM (1977), p. 313

24) 丸山益輝, 福永秀春: 広島大学工学部研究報告, 22 (1973) 1, p. 53

25）精機学会切削性専門委員会: 精密機械, 37 (1971) 5, p. 331

26) $H$. Fukunaga and $M$. Maruyama: Int. Symp. on Influence of Metallurgy on Machinability of Steel, ISIJ/ASM (1977), p. 241 